\title{
Spatiotemporal dynamics of urban climate during the wet-dry season transition in a tropical African city
}

\author{
Peter Kabano $^{1,2}$ (D) Angela Harris $^{1}$ (D) $\cdot$ Sarah Lindley $^{1}$ (I) \\ Received: 12 May 2020 / Revised: 29 October 2020 / Accepted: 1 December 2020 / Published online: 6 January 2021 \\ (C) The Author(s) 2020
}

\begin{abstract}
The Urban Heat Island effect has been the focus of several studies concerned with the effects of urbanisation on human and ecosystem health. Humidity, however, remains much less studied, although it is useful for characterising human thermal comfort, the Urban Dryness Island effect and vegetation development. Furthermore, variability in microscale climate due to differences in land cover is increasingly crucial for understanding urbanisation effects on the health and wellbeing of living organisms. We used regression analysis to investigate the spatial and temporal dynamics of temperature, humidity and heat index in the tropical African city of Kampala, Uganda. We gathered data during the wet to dry season transition from 22 locations that represent the wide range of urban morphological differences in Kampala. Our analysis showed that the advancement of the dry season increased variability of climate in Kampala and that the most built-up locations experienced the most profound seasonal changes in climate. This work stresses the need to account for water availability and humidity to improve our understanding of human and ecosystem health in cities.
\end{abstract}

Keywords Tropics $\cdot$ Urban climate $\cdot$ Seasons $\cdot$ Temperature $\cdot$ Humidity $\cdot$ Heat index $\cdot$ Surface moisture $\cdot$ Regression models

\section{Introduction}

The replacement of natural vegetation and pervious land cover with impervious cover, and intensified human activity (e.g. heavier traffic) through urbanisation alter the cycling of materials and energy in the atmosphere and near-surface (Pataki et al. 2011; Pickett et al. 2011; Wu 2014). Artificial surfaces (e.g. concrete, asphalt and metal) and the compact nature of cities (i.e. high building density, tall buildings, narrow streets)

Peter Kabano

ptkabano@gmail.com

Angela Harris

sarah.lindley@manchester.ac.uk

Sarah Lindley

angela.harris@manchester.ac.uk

1 Department of Geography, School of Environment, Education \& Development, The University of Manchester, Manchester, UK

2 Department of Urban and Regional Planning and Geo-information Management, Faculty of Geo-Information Science and Earth Observation (ITC), University of Twente,

Enschede, The Netherlands promote the transformation of short wave radiation into heat and its retention (Landsberg 1981; Oke 1987), and restricts latent heat flux through evapotranspiration (Taha 1997; Weng et al. 2004; Feyisa et al. 2014; Duarte et al. 2015). Consequently, cities experience warmer temperatures in what is commonly referred to as the Urban Heat Island effect (Landsberg 1981; Voogt and Oke 2003; Heisler and Brazel 2010). The Urban Heat Island (UHI) effect has received considerable critical attention because of its adverse effects on public health and wellbeing through increased heat exposure (Heaviside et al. 2017). Traditionally, UHI studies involve comparing temperatures between urban and rural meteorological stations (Stewart and Oke 2012). However, heterogeneity in surface cover and structure within cities necessitates consideration of microscale climatic processes (Oke 2008; Roth 2012). Much research has been done to date to understand how individual aspects of urban environments (e.g. vegetation) influence urban climate (e.g. Feyisa et al. 2014; Duarte et al. 2015; Giridharan and Emmanuel 2018; Acero and Gonzalez-Asensio 2018). Additionally, the importance of examining the effect of land cover composition as a whole on urban climate has recently gained much attention (Stewart and Oke 2012), and regression modelling is increasingly used for this purpose (Johnson et al. 2020). 
Humidity is an important climatic variable that influences the availability of surface moisture, energy budget, human thermal comfort and ecological systems (Hao et al. 2018; Luo and Lau 2019). Cities generally experience lower humidity than their rural surrounding in what is commonly referred to as the Urban Dryness Island (UDI) effect (Adebayo 1991; Lokoshchenko 2017; Yang et al. 2017). Limited water uptake due to impervious cover (Barnes et al. 2001; Whitford et al. 2001), higher potential evapotranspiration (PET) resulting from the UHI effect and low vegetation cover are the key factors that lead to the formation of the UDI (Hao et al. 2018; Luo and Lau 2019). The UDI also influences the UHI through evapotranspiration, indicating that the two variables are coupled (Lokoshchenko 2017; Hao et al. 2018). In the tropics where surface moisture and humidity are essential indicators of vegetation development (Archibald and Scholes 2007; Jochner et al. 2013; de Camargo et al. 2018), higher plant water requirements due to high PET in cities (Zipper et al. 2017) and UDI might restrict vegetation growth. However, a vast number of tropical urban climate studies have focussed on the UHI effect alone, and far fewer studies have looked at humidity (Giridharan and Emmanuel 2018). Moreover, several studies about the UDI effect have used the urban-rural dichotomy (e.g. Yang et al. 2017; Hao et al. 2018; Luo and Lau 2019), necessitating studying humidity at the neighbourhood (micro) scale.

In the tropics, UHI and UDI intensities weaken during the wet season (Adebayo 1991; Balogun and Balogun 2014; Ayanlade 2016; Ojeh et al. 2016). Roth (2007) suggested that increased thermal admittance of wetter soils in rural areas during the wet season could account for weak UHI intensities. An improved understanding of how moisture availability affects local climate and its variability in cities could be reached using meteorological observations at a high temporal resolution. In the tropics where leaf flush of trees in natural habitats occurs during the wet-dry season transition (de Camargo et al. 2018), information about variability of urban climate could be useful for understanding leaf flush dynamics in cities and how that impacts on thermal cooling and provision of shade for urban residents.

The past decade has seen a significant upward trend in the proportion of tropical UHI studies since the low estimate of $20 \%$ in 2007 (Roth 2007). However, there is a disparity in the number of tropical urban climate studies with respect to geographic regions. Far fewer studies have been done in Africa in comparison to Far East Asia, South Asia and South America (Giridharan and Emmanuel 2018). Moreover, far fewer studies have been done in moist tropical climate types (tropical rainforest, savanna wet and dry and tropical monsoon) in subSaharan Africa. Due to differences in water availability and temperature between tropical climate types (Kottek et al. 2006; Peel et al. 2007), a wide range of exemplar urban climate studies are needed from different tropical climate zones.
Africa is rapidly urbanising, and its urban population is expected to reach 1.26 billion by 2050 from estimates of 400 million (United Nations 2014). Urbanisation in Africa accounts for high losses of natural vegetation cover in cities each year (Yao et al. 2019), although vegetation is strongly depended upon for the provision of urban ecosystem functions like the mitigation of high all-year-round tropical temperatures (du Toit et al. 2018; Lindley et al. 2018). Understanding the climate of tropical African cities could provide information for designing climate-sensitive cities (Heisler and Brazel 2010; Pauleit et al. 2015).

In this paper, we used regression analysis to examine the influence of changes in surface moisture and land cover composition on temperature, humidity and heat index in Kampala, Uganda. Our main objectives were as follows:

- To determine the influence of changes in surface moisture on the local climate in Kampala. We anticipate that spatial variability in urban climate is dependent on changes in surface moisture and variability in local climate within the city increases with the advancement of the dry season

- To establish the relationship between land cover composition and urban climate

\section{Methods}

\section{Study area}

This study was undertaken in Kampala (located at $00^{\circ} 18^{\prime} 49^{\prime \prime}$ $\mathrm{N}, 32^{\circ} 34^{\prime} 52^{\prime \prime} \mathrm{E}$ ), the capital city of Uganda (Fig. 1), with a population density of about 8700 inhabitants $/ \mathrm{km}^{2}$. Kampala has a tropical rainforest (equatorial) climate (Af Köppen climate classification) and experiences two rainy seasons per year, during March-May and September-November. March-May is the shorter of the two rainy seasons, but this season experiences the most torrential rains (approximately $169 \mathrm{~mm}$ ). July receives the least rainfall (approximately 63 $\mathrm{mm}$ ) throughout the entire year. In 2017, the dry season started in May and continued through September (Fig. 2). This study focused on 50 days spanning the wet-dry transition (i.e. Julian day of year (DOY): 100-150).

\section{Meteorological sites and data}

We selected twenty-two sites with varying surface cover and structural characteristics (Fig. 1; Table 1) to account for variation in local climate (Stewart and Oke 2012) and variation in levels of exposure of biological organisms to the effects of urbanisation (Grimm et al. 2008; McCarthy et al. 2010; Pataki et al. 2011; Pickett et al. 2011; Wu 2014). Air temperature and relative humidity data were acquired at each site 


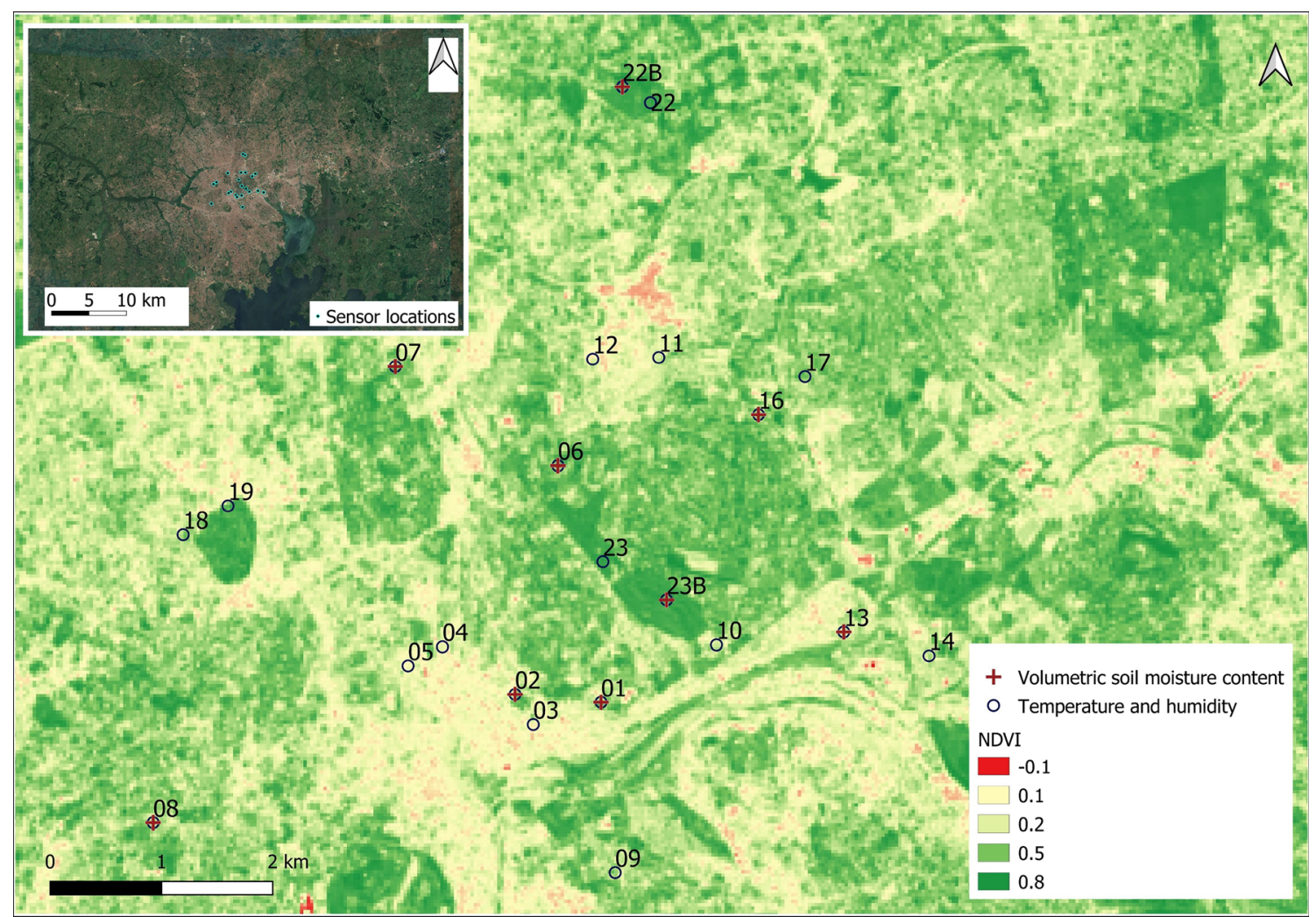

Fig. 1 Location (numbered) of the urban climate monitoring sites and volumetric soil moisture content (crossed) in relation to the proportion of human-made features (and vegetation cover, as indicated by higher values

using i-button sensors (model DS1923, Maxim Integrated) housed in a radiation shield positioned at the height of $3 \mathrm{~m}$ above the ground. The loggers were individually factory calibrated in a NIST (National Institute of Standards and Technology)-traceable chamber before deployment in the field and assessed for drift during data collection. Each sensor collected temperature and relative humidity data at 30-min intervals. of the NDVI (normalised difference vegetation index)). The image in the top left corner shows the selected sites in relation to Kampala's urban extent

As there is no perfect measure of humidity for comparison across sites (Adebayo 1991; Hao et al. 2018), we examined four humidity indicators, including relative humidity (RH), atmospheric water vapour pressure (Ea), specific humidity $(Q)$, and vapour pressure deficit (VPD). The humidity measures were obtained as follows: First, we obtained saturated vapour pressure $(\mathrm{hPa}$; hectopascals) as Es $=6.108 \times$ $\exp [(17.27 \times T) /(273.3 .5+T)]$, where $T$ represents
Fig. 2 Kampala's climate between February and September 2017, depicting monthly rainfall and number of days with more than $1 \mathrm{~mm}$ of rain

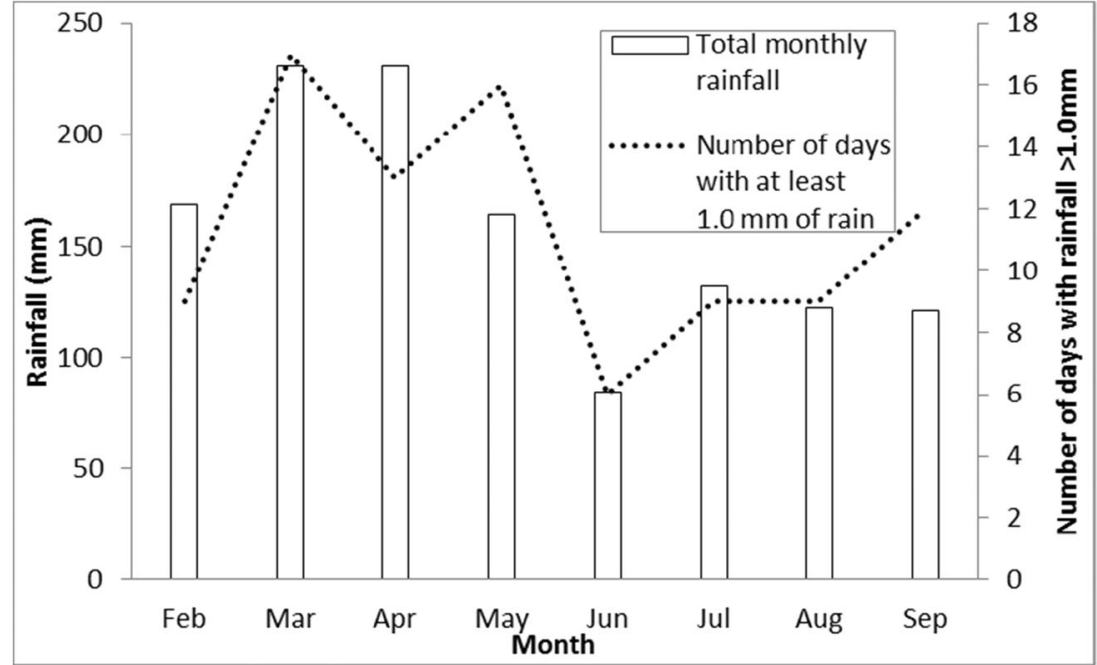


Table 1 The categories of the degree of urbanisation and proportion of different land cover types (impervious cover, paved cover, buildings, trees and pervious cover) at each site. Locations used for observations of surface moisture are in italics

\begin{tabular}{|c|c|c|c|c|c|c|}
\hline $\begin{array}{l}\text { Degree of } \\
\text { urbanisation }\end{array}$ & $\begin{array}{l}\text { Location number } \\
\text { (code) }\end{array}$ & $\begin{array}{l}\text { Impervious } \\
\text { cover }(\%)\end{array}$ & $\begin{array}{l}\text { Paved } \\
\text { cover }(\%)\end{array}$ & $\begin{array}{l}\text { Buildings } \\
(\%)\end{array}$ & $\begin{array}{l}\text { Trees } \\
(\%)\end{array}$ & $\begin{array}{l}\text { Pervious } \\
(\%)\end{array}$ \\
\hline \multirow[t]{6}{*}{ High } & 05 & 84 & 49 & 35 & 5 & 11 \\
\hline & 12 & 81 & 21 & 60 & 6 & 13 \\
\hline & 04 & 80 & 35 & 44 & 9 & 11 \\
\hline & 03 & 79 & 36 & 44 & 9 & 12 \\
\hline & 11 & 69 & 37 & 32 & 11 & 21 \\
\hline & 14 & 65 & 32 & 33 & 13 & 21 \\
\hline \multirow[t]{9}{*}{ Medium } & 13 & 59 & 39 & 21 & 11 & 30 \\
\hline & 10 & 59 & 39 & 21 & 21 & 19 \\
\hline & 01 & 51 & 32 & 20 & 37 & 12 \\
\hline & 09 & 49 & 17 & 32 & 24 & 26 \\
\hline & 02 & 48 & 39 & 9 & 30 & 22 \\
\hline & 17 & 44 & 22 & 22 & 28 & 28 \\
\hline & 18 & 37 & 14 & 23 & 20 & 43 \\
\hline & 16 & 33 & 13 & 20 & 31 & 35 \\
\hline & 08 & 33 & 16 & 17 & 18 & 49 \\
\hline \multirow[t]{7}{*}{ Low } & 07 & 23 & 5 & 19 & 35 & 42 \\
\hline & 06 & 19 & 10 & 9 & 15 & 65 \\
\hline & 19 & 19 & 11 & 8 & 31 & 50 \\
\hline & 23 & 9 & 8 & 1 & 43 & 48 \\
\hline & 22 & 5 & 4 & 2 & 50 & 45 \\
\hline & $22 B$ & 0 & 0 & 0 & 60 & 40 \\
\hline & $23 B$ & 0 & 0 & 0 & 44 & 56 \\
\hline
\end{tabular}

temperature $\left({ }^{\circ} \mathrm{C}\right)$; vapour pressure $(\mathrm{hPa})$ was acquired using the equation $\mathrm{Ea}=\mathrm{Es} \times \mathrm{RH} / 100$; VPD in $\mathrm{hPa}$ was defined as the difference between Ea and Es: VPD = Es - Ea; specific humidity $(Q, \mathrm{~g} / \mathrm{kg})$ was estimated using the equation $Q=(622 \times \mathrm{Ea}) /(P-0.378 \times \mathrm{Ea})$, in which $P$ is pressure in $\mathrm{hPa}$.

A bi-quadratic function that estimates human heat exposure using temperature $(T)$ and relative humidity $(\mathrm{RH})$ observations was used to calculate heat index (HI), as follows:

$$
\begin{aligned}
\mathrm{HI}= & c_{1}+c_{2} T+c_{3} \mathrm{RH}+c_{4} T \mathrm{RH}+c_{5} T^{2}+c_{6} \mathrm{RH}^{2} \\
& +c_{7} T^{2} \mathrm{RH}+c_{8} T \mathrm{RH}^{2}+c_{9} T^{2} \mathrm{RH}^{2}
\end{aligned}
$$

where $c_{1}=-42.379, c_{2}=2.04901523, c_{3}=10.14333127$, $c_{4}=-0.22475541, c_{5}=-0.00683783, c_{6}=-0.05481717, c_{7}$ $=0.00122874, c_{8}=0.00085282$, and $c_{9}=-0.00000199$ (Steadman 1979).

We obtained the daytime and nighttime (sunset 18:00 to sunrise 06:00) averages for each climatic variable each day at each location, and the daily mean and standard deviation across all sites. This way, the standard deviation was used to represent intra-urban climatic variability across time (Adebayo 1991). The time series for each meteorological variable are presented in the supplementary material (Fig A1 and Fig A2).

\section{Characterisation of meteorological sites}

The urban environment was characterised via an ObjectBased Image Analysis classification of a WorldView3 satellite image (spatial resolution of $0.5 \mathrm{~m}$ ) taken on 25/10/2016. Buildings, paved cover, pervious cover (grass and bare soils) and trees were classified and their proportion (percentage) at each site quantified within $200 \mathrm{~m}$. Although a radius of $200 \mathrm{~m}$ has been recommended as the zone for attribution of local climate to land cover composition (Stewart and Oke 2012), the land cover in our candidate sites was heterogeneous. Therefore, the representativeness of an area of a 200-m radius for attributing local climate to land cover was compared to the effectiveness of a smaller area (radius of $100 \mathrm{~m}$ ) with less land cover heterogeneity.

Each site was assigned to one of three categories representing the degree of urbanisation (i.e. high, medium and low) using hierarchical cluster analysis for the 100-m and 200-m land cover data separately. Analysis of similarity (ANOSIM) (Clarke 1993) was used to statistically examine whether urban climate varied significantly between the three categories of degree of urbanisation for the 100-m vs $200-\mathrm{m}$ data. The ANOSIM indicated that the $100 \mathrm{~m}$ dataset showed more significant differences in urban climate between categories of the degree of urbanisation than the 200-m radius $(R=$ 
$0.556(p=0.001)$ and $R=0.321(p=0.005)$; respectively). Therefore, subsequent analysis on the influence of landcover on urban climate was based on land cover within a radius of $100 \mathrm{~m}$ of each meteorological site (Table 1).

\section{Data on surface moisture changes}

Soil volumetric moisture content (VMC; Table 1) was measured in nine sites to relate changes in surface moisture to changes in urban climate and its variability across Kampala. Soil VMC (expressed as a percentage) was measured twice a week using a ThetaProbe (model ML3 ThetaProbe, Delta-T Devices), at five points at each site. The VMC data were temporally interpolated using a locally weighted regression (loess) model to derive a daily time series of surface moisture across Kampala (Fig. 3). The day of year (DOY) when VMC was greatest marked the end of the wet season and the start of the dry season (Fig. 3).

\section{Data analysis}

\section{Influence of soil moisture on urban climate}

Linear regression modelling was used to determine the influence of changes in surface moisture on climate and its variability within Kampala. We used daily VMC aggregated across all sites as the predictor variable and the daily mean and standard deviation of urban climate (temperature, humidity and heat index) as response variables. Location 13 was dropped from the analysis of urban climate patterns due to gaps in data, but was used for VMC data. Linear mixed models (Baayen 2008) were used to determine the effect of degree of urbanisation (proportion of human-made features (paved cover and buildings)) on temporal changes in urban climate with the advancement of the dry season.

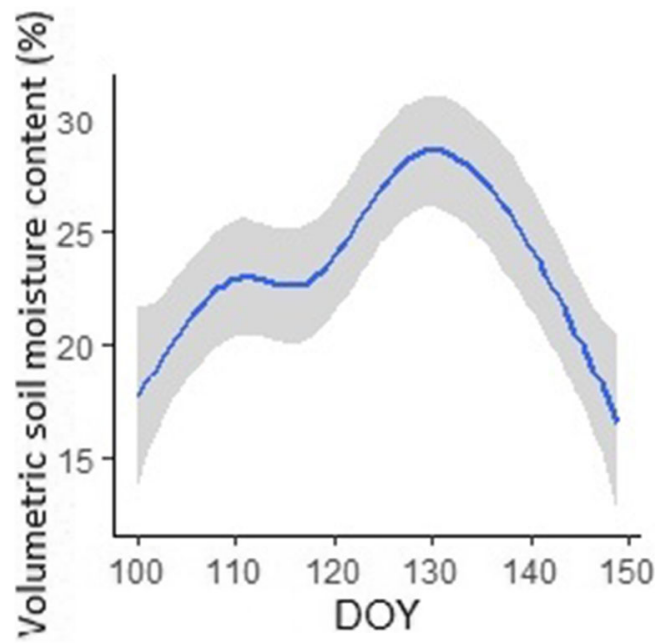

Fig. 3 Temporal change in soil moisture across Kampala for delineation of the wet and dry seasons (DOY $=129$ ). The error band shows the $95 \%$ confidence limits
The proportion of impervious cover (i.e. the proportion of buildings and paved cover) and Julian day (DOY) and their interaction were used as fixed effects (predictor variables). Each data point in each model represented the urban climatic data on a given day at a given location. Individual location was included as a random effect for correlated error terms caused by repeated measures taken at the same location. The significance of the full model was determined using a likelihood ratio test comparing the full model to a null model (lacking the temporal autocorrelation structure). Visual inspection of residuals plotted against fitted values revealed normally distributed and homogeneous residuals. The modelling was done in $\mathrm{R}$ using the "nlme" package (Pinheiro et al. 2018; R Core Team 2018) and the effects visualised with the R package "effects" (Fox and Weisberg 2018).

\section{Influence of land cover composition}

The relative influence of land cover composition on urban climate (nighttime temperature, humidity and heat index) averaged across the dry and wet seasons separately was assessed using an information-theoretic approach (Burnham et al. 2011). Regression models were formulated using combinations of indicators of land cover (i.e. the proportion of paved cover, pervious cover, buildings and trees) as predictors of urban climate for the wet and dry seasons separately. Collinearity between predictor variables was assessed by calculating variance inflation factors ("vif" function of the R package car) for each model, and variables with VIF $>3$ subsequently removed from the models. The explanatory effect of other variables not covered under the scope of this study was accounted for by including a null model in each set of models. Model selection was undertaken using the MuMIn package in $\mathrm{R}$ ( $\mathrm{R}$ version 3.5.0 (Barton 2018; R Core Team 2018)) to identify models with the simplest structure that best predicted urban climate. Ranking of models was performed using the Akaike Information Criterion (AICc) corrected for small samples. The significance of predictor variables was weak if the null model (intercept only) had a $\triangle \mathrm{AICc}=0$. Models with $\Delta$ AIC $<2$ were considered as potentially suitable models. Variables that best predicted urban climate were identified from the relative importance values (RIV) derived from the sum of Akaike weights (Burnham and Anderson 2003).

\section{Results \\ Influence of soil moisture on urban climate}

Specific humidity, vapour pressure and relative humidity increased across Kampala with an increase in surface moisture (Fig. 4). An increase in surface moisture resulted in a decline in temperature and vapour pressure deficit. The sensitivity of urban climate to changes in soil moisture showed diurnal 
variation as evidenced by the significance of the fitted models and coefficients of determination (Fig. 4). Greater levels of sensitivity to changes in soil moisture were observed for nighttime temperature, daytime specific humidity, daytime vapour pressure, nightime relative humidity and nighttime vapour pressure deficit. However, heat index marginally declined with an increase in surface moisture.

Increase in surface moisture across Kampala resulted in a decline in spatial differences in urban climate (Fig. 5). Moreover, changes in spatial differences in urban climate varied diurnally. The urban climate variables whose spatial differences were most affected by changes in surface moisture include nigttime temperature, daytime specific humidity, daytime vapour pressure, nighttime relative humidity, nighttime vapour pressure deficit and nighttime heat index. The linear mixed models showed that the most built-up locations experienced the fastest changes in nighttime temperature, heat index, relative humidity, vapour pressure deficit, specific humidity and vapour pressure (Fig. 6; Fig A3 in supplementary material). The most built-up locations (approximately $80 \%$ impervious cover) showed the highest temperature, highest vapour pressure deficit, highest heat index, lowest specific humidity, lowest relative humidity and lowest vapour pressure across the dry season.

\section{Influence of land cover on urban climate}

Two candidate models predicting the spatial pattern of nighttime temperature in each season had $\Delta \mathrm{AIC}<2$ (Table 2). The proportion of pervious cover featured in all candidate models for nighttime temperature and had RIV that were more than twice as high as all other variables (Table 3 ). The combined effect of the proportion of pervious and tree cover significantly influenced nighttime temperature during both seasons. Specifically, nighttime temperature increased with a decline in the proportion of pervious cover and trees (Table 4).

There were no models explaining the spatial patterns of daytime specific humidity and atmospheric vapour pressure in the wet season (Table 2), and all predictor variables had low relative importance values (Table 3 ). In the dry season, however, the proportion of pervious and tree cover featured in the candidate models for the spatial variation in specific humidity and vapour pressure (Table 2; Fig A4 in supplementary material) and the two predictor variables had higher RIV scores in the dry than the wet season.

The proportion of trees, buildings, pervious cover and paved surfaces featured in the top candidate models predicting the spatial pattern of relative humidity $(\Delta \mathrm{AIC}<2)$. However, there were variations in the main predictor variables between the wet and dry seasons (Table 2). All predictor variables featured in the candidate models for vapour pressure deficit in both seasons. Proportions of pervious surfaces had the highest RIV score, followed by the proportion of tree cover for both vapour pressure deficit and relative humidity (Table 3). Increase in proportion of pervious cover and trees was associated with an increase in relative humidity and decline in vapour pressure deficit (Table 4). All predictor variables featured in the candidate models predicting heat index with pervious cover recording the highest RIV score. An increase in the proportion of pervious and tree cover resulted in a decline in heat index (Table 4).

\section{Discussion}

We empirically examined the spatiotemporal dynamics of urban climate in Kampala during the wet to dry season transition using a network of 22 locations that varied in terms of surface cover and structure (0 to $84 \%$ human-made impervious surfaces). This study showed the synergistic effect of seasonal changes in surface moisture and land cover composition on microscale climate. The effect of land cover composition on intra-urban climatic differences varied with changes in surface moisture. While gradual increases in surface moisture resulted in a decline in intra-urban climatic differences, diminishing water availability intensified intra-urban climatic differences.
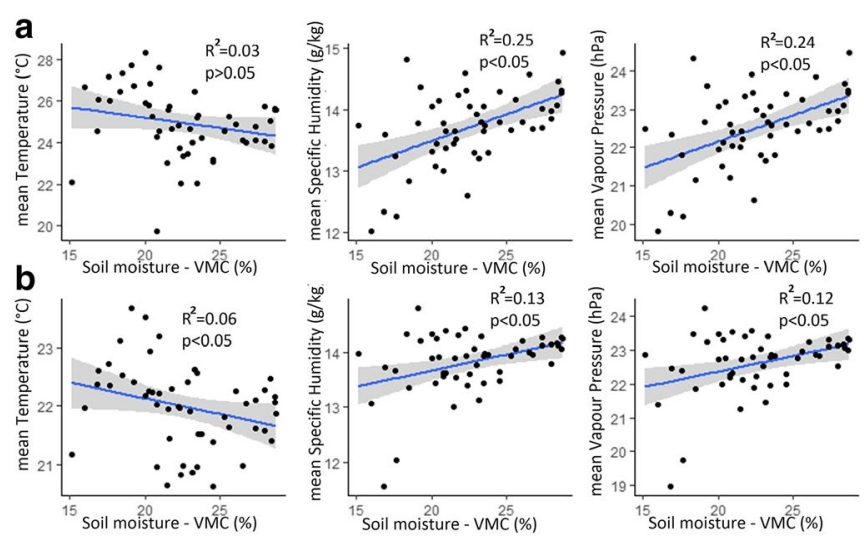
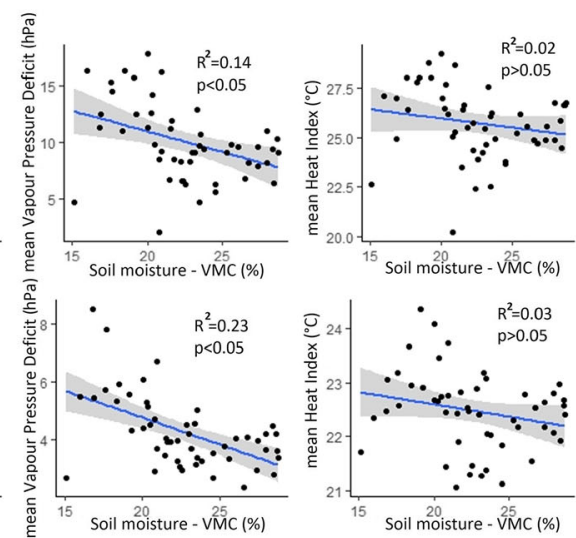

Fig. 4 Relationship between surface moisture and $\mathbf{a}$ daytime climate and $\mathbf{b}$ nighttime climate in Kampala using linear regression analysis 

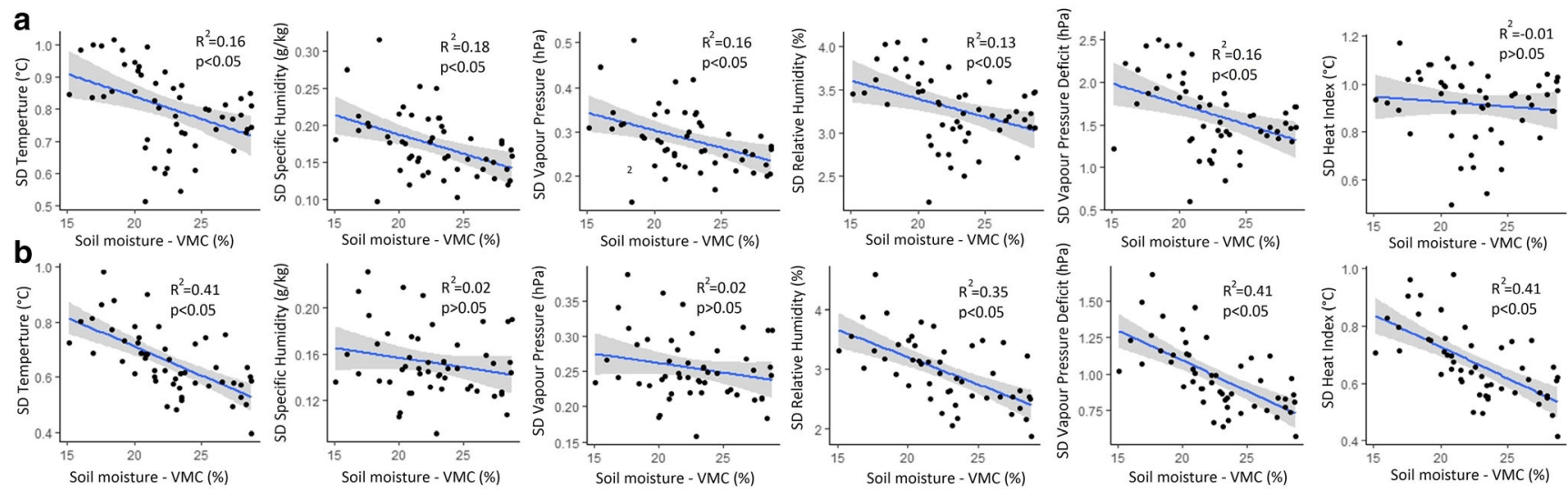

Fig. 5 Relationship between spatial differences in $\mathbf{a}$ daytime climate and $\mathbf{b}$ nighttime climate in Kampala using linear regression analysis

The most built-up locations experienced the fastest changes in urban climate. The proportion of pervious surfaces and trees accounted for spatial differences in temperature, heat index, relative humidity and vapour pressure deficit during both seasons. Specific humidity and vapour pressure had an association with land cover only in the dry season. Higher coefficients of determination for the relationship between land cover composition and urban climate were observed for relative humidity and vapour pressure deficit. We also observed diurnal differences for changes in urban climate and its variation across Kampala.

Spatial differences in urban climate in relation to the proportion of human-made features were observed at all points in time. In contrast to less built-up locations, heavily built-up areas experienced higher nighttime temperature, high heat index, high vapour pressure deficit and lower humidity (i.e. vapour pressure and specific humidity) at any given point in time. Similar findings have been observed in regard to spatial variation in temperature (Cavan et al. 2014; Feyisa et al. 2014), humidity (Adebayo 1991; Yang et al. 2017; Hao et al. 2018; Luo and Lau 2019) and heat index (Hass et al. 2016; Scott et al. 2017). Materials such as concrete and asphalt and the presence of buildings promote the transformation of shortwave radiation into heat and its retention (Landsberg 1981; Oke 1987). The absence of vegetation in cities limits latent heat flux from greater evapotranspiration, resulting in
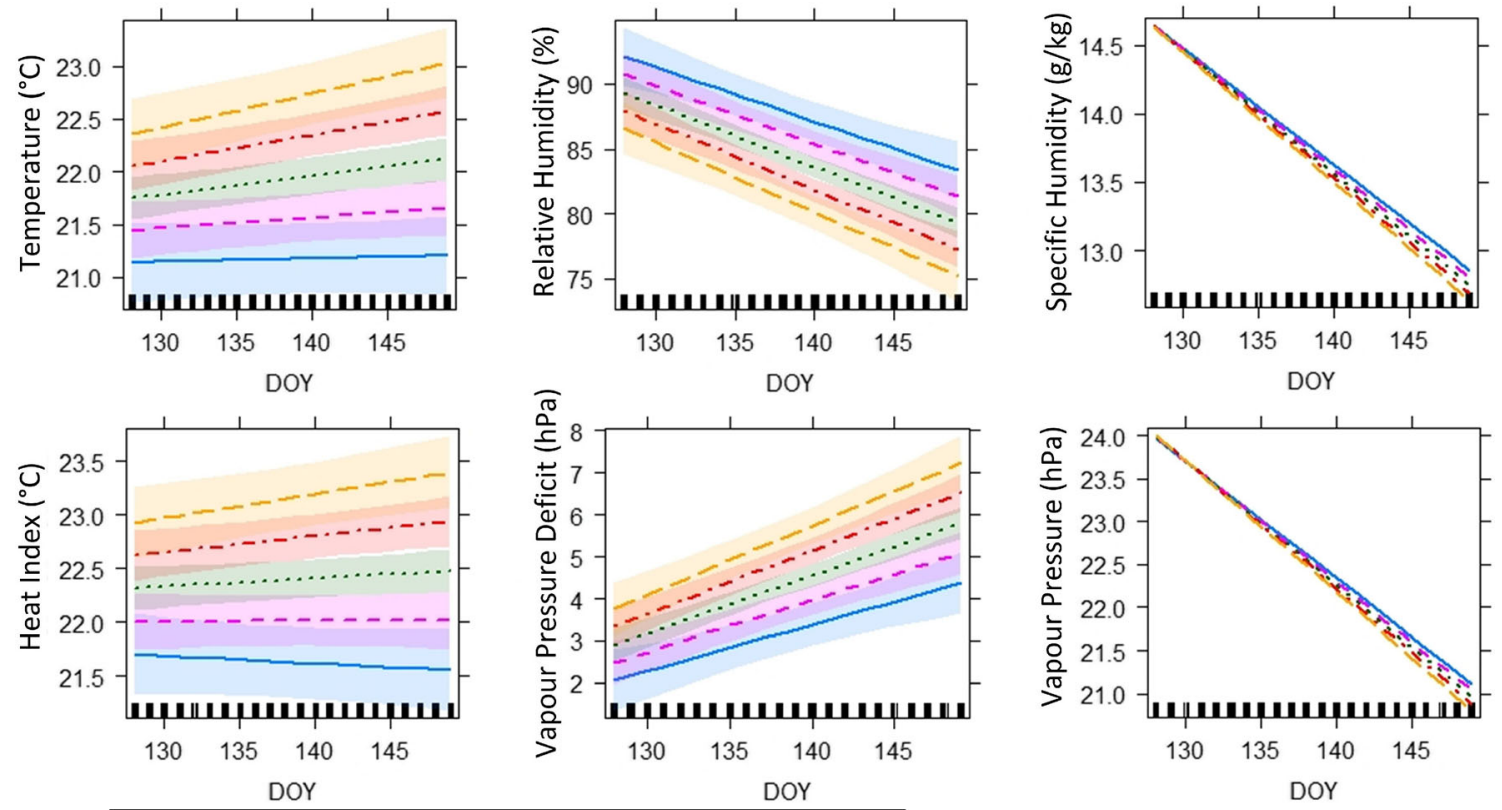

Proportion of impervious cover (\%)

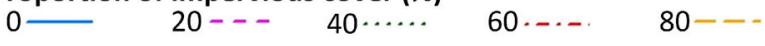

Fig. 6 Effect plots showing modelled (linear mixed models) temporal changes in urban climate (with $95 \%$ confidence bands) in relation to the proportion of human-made features with the advancement of the dry season. Urban climate variables include nighttime temperature, nighttime heat index, nighttime relative humidity, nighttime vapour pressure deficit, daytime vapour pressure and daytime specific humidity that showed high spatial variation with change in surface moisture 
Table 2 Results for regression models for determinants of urban climate during the wet and dry season

\begin{tabular}{|c|c|c|c|c|c|c|c|c|c|}
\hline Variable & Season & Model variables & $\mathrm{AICc}$ & $\log$ Lik & $\mathrm{df}$ & $R^{2}$ & $p$ & Delta & Weight \\
\hline \multirow[t]{4}{*}{ Temperature } & \multirow[t]{2}{*}{ Wet } & Pervious & 21.248 & -6.87 & 3 & 64.8 & $1.13 \mathrm{E}-05$ & 0 & 0.692 \\
\hline & & Pervious, trees & 22.864 & -6.1 & 4 & 65.51 & $4.57 \mathrm{E}-05$ & 1.616 & 0.308 \\
\hline & \multirow[t]{2}{*}{ Dry } & Pervious & 23.89 & -8.19 & 3 & 65.05 & $1.06 \mathrm{E}-05$ & 0 & 0.723 \\
\hline & & Pervious, trees & 25.804 & -7.57 & 4 & 65.24 & $4.88 \mathrm{E}-05$ & 1.914 & 0.277 \\
\hline \multirow[t]{6}{*}{ Specific humidity (SH) } & Wet & Intercept only & -20.032 & 12.37 & 2 & & & 0 & 1 \\
\hline & \multirow[t]{5}{*}{ Dry } & Intercept only & -20.897 & 12.8 & 2 & & & 0 & 0.294 \\
\hline & & Paved & -20.206 & 13.85 & 3 & 5 & 0.1747 & 0.691 & 0.208 \\
\hline & & Pervious & -20.012 & 13.76 & 3 & 4.1 & 0.1961 & 0.885 & 0.189 \\
\hline & & Trees & -19.735 & 13.62 & 3 & 2.7 & 0.232 & 1.163 & 0.165 \\
\hline & & Buildings & -19.469 & 13.48 & 3 & 1.4 & 0.2742 & 1.428 & 0.144 \\
\hline \multirow[t]{5}{*}{ Vapour pressure } & Wet & Intercept only & 0.183 & 2.26 & 2 & & & 0 & 1 \\
\hline & \multirow[t]{4}{*}{ Dry } & Intercept only & -1.458 & 3.08 & 2 & & & 0 & 0.44 \\
\hline & & Paved & 0.097 & 3.7 & 3 & 0.8 & 0.2976 & 1.555 & 0.202 \\
\hline & & Pervious & 0.261 & 3.62 & 3 & -0.03 & 0.332 & 1.719 & 0.186 \\
\hline & & Trees & 0.435 & 3.53 & 3 & -0.9 & 0.3746 & 1.894 & 0.171 \\
\hline \multirow[t]{5}{*}{ Relative humidity (RH) } & \multirow[t]{3}{*}{ Wet } & Pervious, trees & 74.648 & -31.99 & 4 & 76.16 & $1.98 \mathrm{E}-06$ & 0 & 0.498 \\
\hline & & Paved, buildings & 75.675 & -32.5 & 4 & 74.91 & $3.06 \mathrm{E}-06$ & 1.027 & 0.298 \\
\hline & & Pervious & 76.439 & -34.47 & 3 & 71.15 & $1.82 \mathrm{E}-06$ & 1.791 & 0.204 \\
\hline & \multirow[t]{2}{*}{ Dry } & Pervious, trees & 74.515 & -31.92 & 4 & 79.4 & $5.72 \mathrm{E}-07$ & 0 & 0.659 \\
\hline & & Pervious & 75.833 & -34.17 & 3 & 75.65 & $3.85 \mathrm{E}-07$ & 1.318 & 0.341 \\
\hline \multirow[t]{4}{*}{ Vapour pressure deficit (VPD) } & \multirow[t]{2}{*}{ Wet } & Pervious, trees & 38.661 & -14 & 4 & 74.85 & $3.12 \mathrm{E}-06$ & 0 & 0.563 \\
\hline & & Paved, buildings & 39.165 & -14.25 & 4 & 74.21 & $3.86 \mathrm{E}-06$ & 0.504 & 0.437 \\
\hline & \multirow[t]{2}{*}{ Dry } & Pervious, trees & 40.324 & -14.83 & 4 & 77.65 & $1.14 \mathrm{E}-06$ & 0 & 0.642 \\
\hline & & Paved, buildings & 41.496 & -15.41 & 4 & 76.3 & $1.88 \mathrm{E}-06$ & 1.172 & 0.358 \\
\hline \multirow[t]{8}{*}{ Heat index (HI) } & \multirow[t]{4}{*}{ Wet } & Pervious & 22.233 & -7.37 & 3 & 64 & $1.39 \mathrm{E}-05$ & 0 & 0.378 \\
\hline & & Paved & 23.279 & -7.89 & 3 & 62.07 & $2.26 \mathrm{E}-05$ & 1.046 & 0.224 \\
\hline & & Paved, buildings & 23.475 & -6.4 & 4 & 65.38 & $4.72 \mathrm{E}-05$ & 1.241 & 0.203 \\
\hline & & Pervious, trees & 23.549 & -6.44 & 4 & 65.25 & $4.87 \mathrm{E}-05$ & 1.316 & 0.196 \\
\hline & \multirow[t]{4}{*}{ Dry } & Pervious & 24.502 & -8.5 & 3 & 64.3 & $1.29 \mathrm{E}-05$ & 0 & 0.427 \\
\hline & & Paved & 26.011 & -9.26 & 3 & 61.51 & $2.58 \mathrm{E}-05$ & 1.509 & 0.201 \\
\hline & & Pervious, trees & 26.061 & -7.7 & 4 & 65.12 & $5.02 \mathrm{E}-05$ & 1.559 & 0.196 \\
\hline & & Paved, buildings & 26.279 & -7.81 & 4 & 64.74 & $5.51 \mathrm{E}-05$ & 1.777 & 0.176 \\
\hline
\end{tabular}

Table 3 Relative importance values (RIV) of determinants of urban climate

\begin{tabular}{llllll}
\hline Urban climate & Season & Paved surface & Pervious surface & Buildings & Trees \\
\hline Temperature & Wet & 0.28 & 0.71 & 0.23 & 0.23 \\
Temperature & Dry & 0.24 & 0.76 & 0.21 & 0.21 \\
SH & Wet & 0.169 & 0.158 & 0.158 & 0.168 \\
SH & Dry & 0.255 & 0.232 & 0.196 & 0.216 \\
AVP & Wet & 0.16 & 0.162 & 0.162 & 0.16 \\
AVP & Dry & 0.218 & 0.201 & 0.18 & 0.192 \\
RH & Wet & 0.29 & 0.71 & 0.36 & 0.45 \\
RH & Dry & 0.18 & 0.82 & 0.28 & 0.47 \\
VPD & Wet & 0.37 & 0.62 & 0.42 & 0.45 \\
VPD & Dry & 0.28 & 0.72 & 0.36 & 0.48 \\
HI & Wet & 0.43 & 0.57 & 0.25 & 0.23 \\
HI & Dry & 0.37 & 0.62 & 0.23 & 0.22 \\
\hline
\end{tabular}


Table 4 Estimated regression parameters, standard errors (in brackets) and significance levels for the influence of the proportion of pervious and tree cover on urban climate

\begin{tabular}{|c|c|c|c|c|c|c|c|c|}
\hline & \multicolumn{8}{|c|}{ Dependent variable } \\
\hline & \multicolumn{2}{|l|}{ Temperature } & \multicolumn{2}{|c|}{ Relative humidity } & \multicolumn{2}{|c|}{ Vapour pressure deficit } & \multicolumn{2}{|l|}{ Heat index } \\
\hline & (Wet) & (Dry) & (Wet) & (Dry) & (Wet) & (Dry) & (Wet) & (Dry) \\
\hline Pervious surfaces & $\begin{array}{l}-0.027 * * * \\
(0.007)\end{array}$ & $\begin{array}{l}-0.030^{* * *} \\
(0.008)\end{array}$ & $\begin{array}{l}0.112 * * * \\
(0.026)\end{array}$ & $\begin{array}{l}0.129 * * * \\
(0.026)\end{array}$ & $\begin{array}{l}-0.049 * * * \\
(0.011)\end{array}$ & $\begin{array}{l}-0.041 * * * \\
(0.011)\end{array}$ & $\begin{array}{l}-0.029 * * * \\
(0.008)\end{array}$ & $\begin{array}{l}-0.027 * * * \\
(0.007)\end{array}$ \\
\hline Trees & $\begin{array}{l}-0.008 \\
(0.007)\end{array}$ & $\begin{array}{l}-0.008 \\
(0.008)\end{array}$ & $\begin{array}{l}0.056 * * \\
(0.026)\end{array}$ & $\begin{array}{l}0.053 * \\
(0.026)\end{array}$ & $\begin{array}{l}-0.025^{* *} \\
(0.011)\end{array}$ & $\begin{array}{l}-0.025^{* *} \\
(0.010)\end{array}$ & $\begin{array}{l}-0.009 \\
(0.008)\end{array}$ & $\begin{array}{l}-0.009 \\
(0.007)\end{array}$ \\
\hline Intercept & $\begin{array}{l}22.749 * * * \\
(0.186)\end{array}$ & $\begin{array}{l}23.151^{* * *} \\
(0.200)\end{array}$ & $\begin{array}{l}75.497 * * * \\
(0.678)\end{array}$ & $\begin{array}{l}72.481 * * * \\
(0.676)\end{array}$ & $\begin{array}{l}9.286 \text { *** } \\
(0.287)\end{array}$ & $\begin{array}{l}8.132 * * * \\
(0.276)\end{array}$ & $\begin{array}{l}23.616^{* * *} \\
(0.201)\end{array}$ & $\begin{array}{l}23.259 * * * \\
(0.189)\end{array}$ \\
\hline$R^{2}$ & 0.691 & 0.689 & 0.787 & 0.816 & 0.800 & 0.775 & 0.688 & 0.689 \\
\hline Adjusted $R^{2}$ & 0.655 & 0.652 & 0.762 & 0.794 & 0.777 & 0.749 & 0.651 & 0.653 \\
\hline$F$ statistic $(\mathrm{df}=2 ; 17)$ & $19.046^{* * *}$ & $18.829 * * *$ & $31.354 * * *$ & $37.616^{* * *}$ & $34.010^{* * *}$ & $29.274 * * *$ & $18.739 * * *$ & $18.840 * * *$ \\
\hline
\end{tabular}

$* p<0.1 ; * * p<0.05 ; * * p<0.01$

warmer temperatures (Chow and Roth 2006; Cavan et al. 2014; Feyisa et al. 2014; Duarte et al. 2015). Additionally, a high proportion of impervious cover restricts water capture and storage, leading to drier neighbourhoods (Whitford et al. 2001). Stronger intra-urban climatic differences with the advancement of the dry season allude to much greater intraurban climatic differences at the peak of the dry season. This finding is consistent with other studies in tropical urban environments that have observed stronger UHIs (Chow and Roth 2006; Balogun and Balogun 2014; Ojeh et al. 2016; Amorim and Dubreuil 2017; Acero and Gonzalez-Asensio 2018) and UDIs in the dry season (Adebayo 1991). The novelty in this study, however, is that we establish these changes at a high temporal resolution (daily variation) in regard to changes in water availability. Moreover, the current study emphasises the importance of microscale climatic differences due to differences in land cover composition in a tropical urban context.

The high heterogeneity in soil type and depth in Kampala restricted our use of VMC data taken from the topmost soil layer to characterise spatiotemporal patterns of soil moisture in relation to land cover composition. Nonetheless, spatiotemporal patterns of surface moisture with respect to urban form could be inferred from measures of humidity as has been done in the case of the UDI effect (Hao et al. 2018; Luo and Lau 2019). Moreover, humidity has a positive relationship with moisture flux (Archibald and Scholes 2007; Yang et al. 2017; Cai et al. 2019). Therefore, higher humidity in lightly built-up locations indicates higher water capture and storage in comparison to heavily built-up urban areas that experience high water loss through runoff (Whitford et al. 2001). Additionally, the gradual increase in humidity and reduction in temperature with an increase in surface moisture show that increased (adequate) soil moisture enhances latent heat flux through evapotranspiration in Kampala. Soil moisture partitions incoming solar and longwave radiation into outgoing longwave radiation, latent, sensible and ground heat flux and higher moisture content would enhance latent heat flux (Lakshmi et al. 2003; Weng et al. 2004; Berland et al. 2017) in the case of Kampala. Heat and moisture fluxes during the wet season are water-limited because adequate water availability supports evapotranspiration (Pablos et al. 2016; Berland et al. 2017). During the dry season, however, the rapid increase in temperature in the heavily built-up locations occurs as a result of lower latent heat flux due to lower surface water content and high potential evapotranspiration (high sensible heat capture) (Zipper et al. 2017). This contrasts with slow increases in temperature in the lightly built-up locations. High water availability in lightly built-up locations sustains evapotranspiration (latent heat flux) over longer periods. The differences in temperature change between heavily and lightly built-up locations during the dry season highlight contrasts in energy and moisture fluxes due to differences in land cover composition and water availability. Moreover, higher plant water requirements due to increased potential evapotranspiration in heavily built-up locations (Zipper et al. 2017) are exacerbated by low water availability leading to low leaf production and high leaf loss in the most built-up locations (Kabano et al. 2020). Due to spatial differences in canopy cover, the variability in thermal regulation via evapotranspiration further intensifies intra-urban differences in temperature with the advancement of the dry season.

Relative humidity is often overlooked because of its sensitivity to temperature and that the two variables mirror one another. In this study, the combined effect of the proportion of pervious cover and trees accounted for more than $75 \%$ of the spatial differences in relative humidity for season averaged data (i.e. both wet and dry seasons). However, we observed much lower coefficients of determination (about 65\%) for the 
effect of pervious cover and trees on temperature, showing the inherent differences between the temperature and relative humidity. Intra-urban differences in temperature are influenced by other variables, including cloud cover, calm conditions and wind (Roth 2012) that were not covered under the scope of this study. Relative humidity is controlled by moisture flux, and surface evaporation, and the relationship between temperature and relative humidity is (temporal) scale-dependent (Yang et al. 2017). Yang et al. (2017) observed that the relationship between monthly and seasonal mean relative humidity and temperature was weak despite hourly relative humidity almost mirroring air temperature. Hao et al. (2018) observed that the decline in relative humidity in the urbanisation process of the Yangtze River Delta had no direct association with changes in air temperature. Moreover, seasonal temperature and relative humidity have been observed to exhibit varying relationships with leaf development (Do et al. 2005; Archibald and Scholes 2007; Jochner et al. 2013) indicating inherent differences between the two variables when examined at a seasonal scale.

\section{Conclusion}

This study provides important evidence about the effect of changes in surface moisture and land cover composition on climate in a city with a tropical rain forest (equatorial) climate type. Although temperature is often the focus of urban climate research, this work addresses the need to include humidity, heat index and water availability to better understand how plant development and heat exposure might be affected by land cover seasonally. Moreover, this work emphasises the importance of examining microscale urban climate processes in relation to neighbourhood characteristics.

In Kampala, the most built-up locations ( $80 \%$ of impervious cover) show the highest heat index and temperature, which are exacerbated with the advancement of the dry season. Our findings show that urban residents in the most builtup parts of the city are the most vulnerable to heat stress, heatrelated health complications (e.g. asthma, air pollution and allergens) and reduced productivity at work (Hass et al. 2016). Moreover, high leaf loss and low leaf production of trees due to low water availability and high temperature in the most built-up locations (Kabano et al. 2020) could further elevate the urban heat during the dry season through reduced rates of thermal cooling and reduced provision of shade. Such information about the relationship between neighbourhood characteristics and micro-scale urban climate could be used by urban planners in Kampala and other fast-developing tropical cities in the Global South to design climate-sensitive cities for improved human health and to maximise the benefits of urban vegetation.
Supplementary Information The online version contains supplementary material available at https://doi.org/10.1007/s00484-020-02061-1.

Acknowledgements We thank staff at Kampala Capital City Authority (Damalie Nyamatte, Isaac Mugumbule and Bernadette Ssanyu) for their assistance acquiring research clearance and access to various sites in Kampala. We also thank Daniel Kanamara, Grace Namugalu, Harriet Kyakyo and Dr. Bernard Barasa for invaluable insights and assistance with the logistics. Thanks to Digital Globe Foundation for providing free WorldView-3 imagery of Kampala, and to the manuscript reviewers for their helpful suggestions.

Author contributions PK, AH and SL designed the study; PK performed the fieldwork and data analysis under the supervision of AH and SL. All authors contributed critically to manuscript drafts. This research was conducted while the first author was a PhD student at The University of Manchester, Manchester, UK

Funding This research was funded by the Commonwealth Scholarship Commission and Prince Albert II of Monaco Foundation through an Intergovernmental Panel for Climate Change Scholarship award.

\section{Compliance with ethical standards}

Conflict of interest The authors declare that they have no conflict of interest.

Open Access This article is licensed under a Creative Commons Attribution 4.0 International License, which permits use, sharing, adaptation, distribution and reproduction in any medium or format, as long as you give appropriate credit to the original author(s) and the source, provide a link to the Creative Commons licence, and indicate if changes were made. The images or other third party material in this article are included in the article's Creative Commons licence, unless indicated otherwise in a credit line to the material. If material is not included in the article's Creative Commons licence and your intended use is not permitted by statutory regulation or exceeds the permitted use, you will need to obtain permission directly from the copyright holder. To view a copy of this licence, visit http://creativecommons.org/licenses/by/4.0/.

\section{References}

Acero JA, Gonzalez-Asensio B (2018) Influence of vegetation on the morning land surface temperature in a tropical humid urban area. Urban Clim 26:231-243. https://doi.org/10.1016/j.uclim.2018.09. 004

Adebayo YR (1991) Day-time effects of urbanization on relative humidity and vapour pressure in a tropical city. Theor Appl Climatol 43: 17-30. https://doi.org/10.1007/BF00865039

Amorim MC d CT, Dubreuil V (2017) Intensity of urban heat islands in tropical and temperate climates. Climate. 5. https://doi.org/10.3390/ cli5040091

Archibald S, Scholes RJ (2007) Leaf green-up in a semi-arid African savanna - separating tree and grass responses to environmental cues. J Veg Sci 18:583-594. https://doi.org/10.1658/1100-9233(2007) 18[583:lgiasa $] 2.0 . c 0 ; 2$

Ayanlade A (2016) Variation in diurnal and seasonal urban land surface temperature: landuse change impacts assessment over Lagos metropolitan city. Model Earth Syst Environ 2:1-8. https://doi.org/10. 1007/s40808-016-0238-z 
Baayen RH (2008) Analyzing linguistic data: a practical introduction to statistics using R. Cambridge University Press, Cambridge

Balogun IA, Balogun AA (2014) Urban heat island and bioclimatological conditions in a hot-humid tropical city: the example of Akure, Nigeria. Erde. https://doi.org/10.12854/erde-145-2

Barnes KB, Morgan J, Roberge M (2001) Impervious surfaces and the quality of natural and built environments. Balt Dep Geogr Environ Planning, Towson Univ

Barton K (2018) MuMIn: multi-model inference

Berland A, Shiflett SA, Shuster WD, Garmestani AS, Goddard HC, Herrmann DL, Hopton ME (2017) The role of trees in urban stormwater management. Landsc Urban Plan 162:167-177. https:/ doi.org/10.1016/j.landurbplan.2017.02.017

Burnham KP, Anderson DR (2003) Model selection and multimodel inference: a practical information-theoretic approach. Springer Science \& Business Media

Burnham KP, Anderson DR, Huyvaert KP (2011) AIC model selection and multimodel inference in behavioral ecology: some background, observations, and comparisons. Behav Ecol Sociobiol 65:23-35. https://doi.org/10.1007/s00265-010-1029-6

Cai Y, Zheng W, Zhang X, Zhangzhong L, Xue X (2019) Research on soil moisture prediction model based on deep learning. PLoS One 14:1-19. https://doi.org/10.1371/journal.pone.0214508

Cavan G, Lindley S, Jalayer F, Yeshitela K, Pauleit S, Renner F, Gill S, Capuano P, Nebebe A, Woldegerima T, Kibassa D, Shemdoe R (2014) Urban morphological determinants of temperature regulating ecosystem services in two African cities. Ecol Indic 42:43-57. https://doi.org/10.1016/j.ecolind.2014.01.025

Chow WTL, Roth M (2006) Temporal dynamics of the urban heat island of Singapore. Int J Climatol 26:2243-2260. https://doi.org/10.1002/ joc. 1364

Clarke KR (1993) Non-parametric multivariate analyses of changes in community structure. Aust J Ecol 18:117-143. https://doi.org/10. 1111/j.1442-9993.1993.tb00438.x

de Camargo MGG, de Carvalho GH, Alberton BD et al (2018) Leafing patterns and leaf exchange strategies of a cerrado woody community. Biotropica 50:442-454. https://doi.org/10.1111/btp.12552

Do FC, Goudiaby VA, Gimenez O, Diagne AL, Diouf M, Rocheteau A, Akpo LE (2005) Environmental influence on canopy phenology in the dry tropics. For Ecol Manag 215:319-328. https://doi.org/10. 1016/j.foreco.2005.05.022

du Toit MJ, Cilliers SS, Dallimer M, Goddard M, Guenat S, Cornelius SF (2018) Urban green infrastructure and ecosystem services in subSaharan Africa. Landsc Urban Plan 180:249-261. https://doi.org/ 10.1016/j.landurbplan.2018.06.001

Duarte DHS, Shinzato P, Gusson C dos S, Alves CA (2015) The impact of vegetation on urban microclimate to counterbalance built density in a subtropical changing climate. Urban Clim 14:224-239. https:// doi.org/10.1016/j.uclim.2015.09.006

Feyisa GL, Dons K, Meilby H (2014) Efficiency of parks in mitigating urban heat island effect: an example from Addis Ababa. Landsc Urban Plan 123:87-95. https://doi.org/10.1016/j.landurbplan.2013. 12.008

Fox J, Weisberg S (2018) Visualizing fit and lack of fit in complex regression models with predictor effect plots and partial residuals. J Stat Softw 87. https://doi.org/10.18637/jss.v087.i09

Giridharan R, Emmanuel R (2018) The impact of urban compactness, comfort strategies and energy consumption on tropical urban heat island intensity: a review. Sustain Cities Soc 40:677-687. https:// doi.org/10.1016/j.scs.2018.01.024

Grimm NB, Faeth SH, Golubiewski NE, Redman CL, Wu J, Bai X, Briggs JM (2008) Global change and the ecology of cities. Science 319(80):756-760. https://doi.org/10.1126/science.1150195

Hao L, Huang X, Qin M, Liu Y, Li W, Sun G (2018) Ecohydrological processes explain urban dry island effects in a wet region, Southern
China. Water Resour Res 54:6757-6771. https://doi.org/10.1029/ 2018WR023002

Hass AL, Ellis KN, Reyes Mason L, Hathaway J, Howe D (2016) Heat and humidity in the city: neighborhood heat index variability in a mid-sized city in the Southeastern United States. Int J Environ Res Public Health 13:17. https://doi.org/10.3390/ijerph13010117

Heaviside C, Macintyre H, Vardoulakis S (2017) The urban heat island: implications for health in a changing environment. Curr Environ Heal Rep 4:296

Heisler GM, Brazel AJ (2010) The Urban Physical Environment: Temperature and Urban Heat Islands. In: Urban Ecosystem Ecology. John Wiley \& Sons, Ltd, pp 29-56

Jochner S, Alves-Eigenheer M, Menzel A, Morellato LPC (2013) Using phenology to assess urban heat islands in tropical and temperate regions. Int J Climatol 33:3141-3151. https://doi.org/10.1002/joc. 3651

Johnson S, Ross Z, Kheirbek I, Ito K (2020) Characterization of intraurban spatial variation in observed summer ambient temperature from the New York City Community Air Survey. Urban Clim 31: 100583. https://doi.org/10.1016/j.uclim.2020.100583

Kabano P, Harris A, Lindley S (2020) Sensitivity of canopy phenology to local urban environmental characteristics in a tropical city. Ecosystems https://doi.org/10.1007/s10021-020-00571-y

Kottek M, Grieser J, Beck C, Rudolf B, Rubel F (2006) World map of the Köppen-Geiger climate classification updated. Meteorol Z 15:259263. https://doi.org/10.1127/0941-2948/2006/0130

Lakshmi V, Jackson TJ, Zehrfuhs D (2003) Soil moisture-temperature relationships: results from two field experiments. Hydrol Process 17: 3041-3057

Landsberg HE (1981) The Urban Climate. Academic Press, New York

Lindley S, Pauleit S, Yeshitela K, Cilliers S, Shackleton C (2018) Rethinking urban green infrastructure and ecosystem services from the perspective of sub-Saharan African cities. Landsc Urban Plan 180:328-338. https://doi.org/10.1016/j.landurbplan.2018.08.016

Lokoshchenko MA (2017) Urban heat island and urban dry island in Moscow and their centennial changes. J Appl Meteorol Climatol 56:2729-2745. https://doi.org/10.1175/JAMC-D-16-0383.1

Luo M, Lau NC (2019) Urban expansion and drying climate in an urban agglomeration of East China. Geophys Res Lett 46:6868-6877. https://doi.org/10.1029/2019GL082736

McCarthy MP, Best MJ, Betts RA (2010) Climate change in cities due to global warming and urban effects. Geophys Res Lett 37. https://doi. org/10.1029/2010gl042845

Ojeh VN, Balogun AA, Okhimamhe AA (2016) Urban-rural temperature differences in Lagos. Climate 4. https://doi.org/10.3390/cli4020029

Oke TR (1987) Boundary Layer Climates. Routledge, London

Oke TR (2008) Urban observations. Guide to meteorological instruments and methods of observation, Part II of Observing Systems, WMONo. 8. World Meteorol Organ II-11-1-II-11-25

Pablos M, Martínez-Fernández J, Piles M, Sánchez N, Vall-1lossera M, Camps A (2016) Multi-temporal evaluation of soil moisture and land surface temperature dynamics using in situ and satellite observations. Remote Sens 8. https://doi.org/10.3390/rs8070587

Pataki DE, Carreiro MM, Cherrier J, Grulke NE, Jennings V, Pincetl S, Pouyat RV, Whitlow TH, Zipperer WC (2011) Coupling biogeochemical cycles in urban environments: ecosystem services, green solutions, and misconceptions. Front Ecol Environ 9:27-36. https:// doi.org/10.1890/090220

Pauleit S, Coly A, Fohlmeister S, et al (2015) Urban vulnerability and climate change in Africa. Futur City 4:

Peel MC, Finlayson BL, McMahon TA (2007) Updated world map of the Köppen-Geiger climate classification. Hydrol Earth Syst Sci 11: 1633-1644. https://doi.org/10.5194/hess-11-1633-2007

Pickett STA, Cadenasso ML, Grove JM, Boone CG, Groffman PM, Irwin E, Kaushal SS, Marshall V, McGrath BP, Nilon CH, Pouyat RV, Szlavecz K, Troy A, Warren P (2011) Urban ecological systems: 
scientific foundations and a decade of progress. J Environ Manag 92:331-362. https://doi.org/10.1016/j.jenvman.2010.08.022

Pinheiro J, Bates D, DebRoy S, et al (2018) \{nlme\}: linear and nonlinear mixed effects models

R Core Team (2018) R: a language and environment for statistical computing

Roth M (2007) Review of urban climate research in (sub)tropical regions. Int J Climatol 27:1859-1873. https://doi.org/10.1002/joc.1591

Roth M (2012) Urban heat islands. In: Handbook of environmental fluid dynamics, vol 2. CRC, Boca Raton, pp 1-587

Scott AA, Misiani H, Okoth J, Jordan A, Gohlke J, Ouma G, Arrighi J, Zaitchik BF, Jjemba E, Verjee S, Waugh DW (2017) Temperature and heat in informal settlements in Nairobi. PLoS One 12:e187300

Steadman RG (1979) A temperature-humidity index based on human physiology and clothing science. J Appl Meteorol 18:861-873

Stewart I, Oke T (2012) Local climate zones for urban temperature studies. Bull Am Meteorol Soc 93:1879-1900

Taha H (1997) Urban climates and heat islands: albedo, evapotranspiration, and anthropogenic heat. Energy Build 25:99-103. https://doi. org/10.1016/S0378-7788(96)00999-1

United Nations (2014) World Urbanization Prospects: 2014 Revision

Voogt JA, Oke TR (2003) Thermal remote sensing of urban climates. Remote Sens Environ 86:370-384. https://doi.org/10.1016/s00344257(03)00079-8
Weng Q, Lu D, Schubring J (2004) Estimation of land surface temperature-vegetation abundance relationship for urban heat island studies. Remote Sens Environ 89:467-483. https://doi.org/10.1016/ j.rse.2003.11.005

Whitford V, Ennos AR, Handley JF (2001) "City form and natural process" - indicators for the ecological performance of urban areas and their application to Merseyside, UK. Landsc Urban Plan 57:91-103. https://doi.org/10.1016/s0169-2046(01)00192-x

Wu JG (2014) Urban ecology and sustainability: the state-of-the-science and future directions. Landsc Urban Plan 125:209-221. https://doi. org/10.1016/j.landurbplan.2014.01.018

Yang P, Ren G, Hou W (2017) Temporal-spatial patterns of relative humidity and the urban dryness island effect in Beijing City. J Appl Meteorol Climatol 56:2221-2237. https://doi.org/10.1175/ JAMC-D-16-0338.1

Yao R, Cao J, Wang LC, Zhang W, Wu X (2019) Urbanization effects on vegetation cover in major African cities during 2001-2017. Int $\mathrm{J}$ Appl Earth Obs Geoinf 75:44-53. https://doi.org/10.1016/j.jag. 2018.10.011

Zipper SC, Schatz J, Kucharik CJ, Loheide SP (2017) Urban heat islandinduced increases in evapotranspirative demand. Geophys Res Lett 44:873-881. https://doi.org/10.1002/2016g1072190

Publisher's note Springer Nature remains neutral with regard to jurisdictional claims in published maps and institutional affiliations. 